\title{
Chapter 41 \\ Noticing in Pre-service Teacher \\ Education: Research Lessons as a Context \\ for Reflection on Learners' Mathematical \\ Reasoning and Sense-Making
}

\author{
Helena Wessels
}

\begin{abstract}
Professional noticing of learners' mathematics reasoning is a crucial ingredient of a mathematics teacher's set of teaching competencies. Research lessons in the lesson study process, with its focus on learner reasoning, provide a structured environment for the building of mathematical knowledge as well as for reflection and the development of teacher professional noticing and sense-making. This paper reports on the depth and growth in noticing of three pre-service teachers during research lessons in their third and fourth years, using the Van Es noticing framework. The study showed that two of these teachers' noticing shifted to higher levels over the two years, with greater focus on learners' mathematical reasoning and sense-making than on teacher actions and teaching. Prospective teachers need well-structured and focused opportunities, individually as well as in groups, to learn to notice and make sense of learner thinking and reasoning.
\end{abstract}

Keywords Professional noticing - Lesson study • Research lessons Mathematical reasoning $\cdot$ Reflective practice

\subsection{Introduction}

The preparation of pre-service teachers to teach mathematics for understanding is an important focus in mathematics education, and the development of reflective practice is one of the cornerstones in this process. Teaching for understanding goes hand in hand with a problem-centred approach to the teaching of mathematics as described in the work of Murray et al. (1998), Hiebert et al. (1997) and Stein et al. (2008). The problem-centred approach is based on the premise that learners build their own conceptual knowledge and mathematical understanding through solving

H. Wessels $(\bowtie)$

Research Unit for Mathematics Education,

Stellenbosch University, Stellenbosch, South Africa

e-mail: hwessels@sun.ac.za

(C) The Author(s) 2018

G. Kaiser et al. (eds.), Invited Lectures from the 13th International Congress

on Mathematical Education, ICME-13 Monographs,

https://doi.org/10.1007/978-3-319-72170-5_41 
problems independently or through interaction with others. Preparing pre-service teachers to teach for understanding using a problem-centred approach is challenging as it is so different from the more traditional way of teaching that they have usually been exposed to during their own school years as well as during school practicums during their studies (Santagata 2011). Prospective teachers therefore need professional development and experience to scaffold their ability to consider children's mathematical responses through a different lens, interpret what they see, and to 'imagine themselves in the future acting responsively and freshly rather than habitually. The mark of improving research capacities for individuals lies in their being able to imagine themselves in the future acting (responding) more appropriately than before' (Mason 2011, p. 38). Research studies have shown that prospective teachers lack in this kind of noticing and lesson analysis skills (Barnhart and Van Es 2015; Santagata 2011).

Pre-service teachers also need repeated opportunities for reflection over time:

[They] are not likely to develop such a complicated array of knowledge, skills, and dispositions simply by watching a video or demonstration lesson or reading standards or articles; they are likely to need repeated cycles of study, trial in the classroom, reflection, refinement, and trial again. (Takahashi et al. 2013, p. 243)

Designing teacher preparation programs that foster the appropriate knowledge, skills and dispositions for pre-service teachers has been an enduring challenge in mathematics education (Hiebert et al. 2003). At Stellenbosch University, lesson study has been implemented in their preparation program for prospective foundation phase teachers for the past five years to develop pre-service teachers' knowledge, skills and dispositions through reflective practice and to scaffold their awareness and interpretation of learners' mathematical reasoning, specifically during lessons (Paolucci and Wessels 2017). The focus of the research described in this paper is on determining the growth and depth of pre-service teachers' noticing of the mathematical reasoning of learners during research lessons over a two-year period in this preparation program.

\subsection{Literature Review}

\subsubsection{Reflection and Professional Noticing}

The linking of theory and practice is one of the crucial issues in teacher education and systematic, purposeful reflection is considered vital in this process (Dewey 1933; Korthagen et al. 2006).

Schön (1987) distinguishes between reflection-in-action and reflection-on-action. Reflection-in-action (in-the-moment decisions) entails teachers' ability during a lesson to reshape what they do while they are doing it, think on their feet and use 
knowledge and experience to interpret the situation and act on it. Thorough preparation and anticipating learner strategies and misconceptions provide points of reference for reflection-in-action and enable didactical flexibility. Reflection-on-action (looking back), on the other hand, entails the often-documented looking back after an experience and reflecting on what happened and why it happened. Both these notions play an important role in preparing pre-service teachers to bridge the gap between theory and practice and become reflective practitioners. However, pre-service teachers often do not know what to reflect on or how to reflect in lessons they observe: 'Without structured support and appropriate framing, pre-service teachers' analyses tend to focus on the actions and behaviors of the teacher rather than student thinking, learning and sense-making and tend to be judgmental and lack evidential support and coherence' (Barnhardt and Van Es 2015, p. 84).

Noticing can be described as one of the core practices in mathematics teacher education (Choy 2016; Grossman et al. 2009) and can provide appropriate support and framing for the development of productive reflection on learners' mathematical reasoning during lessons. A growing number of researchers regard teacher noticing as a useful framework for promoting adaptive and responsive teaching and for in-service and prospective teachers to learn from their teaching by focusing on learner mathematical reasoning (Sherin et al. 2011a). Galbraith (2015) describes noticing as 'an essential ability of a perceptive and effective mathematics teacher' (p. 151). It entails attending to student mathematical reasoning and making sense of this information to inform teaching decisions and teacher moves. Noticing is referred to in different ways in the literature: a discipline and an intentional systematic set of practices (Mason 2002), the sizing up of students' ideas and responding (Ball et al. 2001), a set of skills (Jacobs et al. 2010), two processes (Sherin et al. 2011a) and a goal-oriented decision-making process (Schoenfeld 2011). Noticing progresses through three interrelated phases: attending to learner mathematical reasoning in classroom interactions, the interpretation of learner reasoning in this setting and deciding what actions should be taken based on inferences from this analysis (Barnhart and Van Es 2015; Jacobs et al. 2010; Van Es 2011). The three phases can entail reflection-in-action of the teacher during the lesson as well as reflection-on-action during the post-lesson discussion by observers and the teacher who taught the lesson (Schön 1987). The three phases are intertwined: 'three component skills, but also an integrated set' (Jacobs et al. 2010, pp. 173, 174).

Noticing can be influenced by several factors, including mathematical knowledge for teaching (Kazemi et al. 2011; Schoenfeld 2011; Seidel and Stürmer 2014), beliefs (Erickson 2011; Goldsmith et al. 2014; Schoenfeld 2011), prior experience (Erickson 2011), context (Mitchell and Marin 2015; Seidel and Stürmer 2014) and pedagogical commitment of the teacher (Erickson 2011). It is therefore important that noticing be regarded 'within the wider context of the teachers' growing knowledge (resources), goals, and orientations' (Schoenfeld 2011, p. 237). 


\subsubsection{Frameworks for Analysing Professional Noticing}

With the increase in research studies on teacher noticing, different frameworks have been developed to analyse and assess teachers' noticing. Examples are the Mathematical Quality of Instruction (MQI) analysis framework of Hill et al. (2008) as used by Mitchell and Marin (2015) to support noticing, the Van Es (2011) framework for learning to notice, the Santagata (2011) lesson analysis framework and the Choy (2015) FOCUS framework for task development. Other frameworks are focused on specific mathematical content, for example, the Fernández et al. (2013) framework for the development of teachers' noticing of students' mathematical thinking in the context of proportionality.

The Van Es (2011) framework was chosen for the research study in this paper as its focus on the content and levels of noticing and the trajectory for the development of noticing was useful to analyse growth and depth in pre-service teachers' reflections over time. The Van Es framework (Table 41.1) first focuses on two

Table 41.1 Framework for learning to notice student mathematical thinking (Van Es 2011, p. 139)

\begin{tabular}{|c|c|c|}
\hline & What teachers notice & How teachers notice \\
\hline \multirow[t]{3}{*}{$\begin{array}{l}\text { Level } 1 \\
\text { Baseline }\end{array}$} & \multirow[t]{3}{*}{$\begin{array}{l}\text { Attend to whole class environment, } \\
\text { behaviour, learning and teacher pedagogy }\end{array}$} & $\begin{array}{l}\text { Form general impressions of what } \\
\text { occurred }\end{array}$ \\
\hline & & $\begin{array}{l}\text { Provide descriptive and evaluative } \\
\text { comments }\end{array}$ \\
\hline & & $\begin{array}{l}\text { Provide little or no evidence to } \\
\text { support analysis }\end{array}$ \\
\hline \multirow[t]{3}{*}{$\begin{array}{l}\text { Level } 2 \\
\text { Mixed }\end{array}$} & \multirow{3}{*}{$\begin{array}{l}\text { Primarily attend to teacher pedagogy } \\
\text { Begin to attend to particular students' } \\
\text { mathematical thinking and behaviours }\end{array}$} & $\begin{array}{l}\text { Form general impressions and } \\
\text { highlight noteworthy events }\end{array}$ \\
\hline & & $\begin{array}{l}\text { Provide primarily evaluative with } \\
\text { some interpretive comments }\end{array}$ \\
\hline & & $\begin{array}{l}\text { Begin to refer to specific events and } \\
\text { interactions as evidence }\end{array}$ \\
\hline \multirow{3}{*}{$\begin{array}{l}\text { Level } 3 \\
\text { Focused }\end{array}$} & \multirow{3}{*}{$\begin{array}{l}\text { Attend to particular students' mathematical } \\
\text { thinking }\end{array}$} & Provide interpretive comments \\
\hline & & $\begin{array}{l}\text { Refer to specific events and } \\
\text { interactions as evidence }\end{array}$ \\
\hline & & Elaborate on events and interactions \\
\hline \multirow{5}{*}{$\begin{array}{l}\text { Level } 4 \\
\text { Extended }\end{array}$} & \multirow{5}{*}{$\begin{array}{l}\text { Attend to the relationship between particular } \\
\text { students' mathematical thinking and } \\
\text { between teaching strategies and student } \\
\text { mathematical thinking }\end{array}$} & Provide interpretive comments \\
\hline & & $\begin{array}{l}\text { Refer to specific events and } \\
\text { interactions as evidence }\end{array}$ \\
\hline & & Elaborate on events and interactions \\
\hline & & $\begin{array}{l}\text { Make connections between events } \\
\text { and principles of teaching and } \\
\text { learning }\end{array}$ \\
\hline & & $\begin{array}{l}\text { On the basis of interpretations, } \\
\text { propose alternative pedagogical } \\
\text { solutions }\end{array}$ \\
\hline
\end{tabular}


central dimensions of noticing: what teachers notice and how teachers analyse what they notice. What teachers notice includes whom they notice (learners as class or group, individual learners, teacher, self) as well as the topic of their noticing (learner behaviour, mathematical reasoning, teacher pedagogy). How they analyse refers to an analytic, evaluative, interpretive or deep analysis of what they notice. Second, the framework provides a trajectory of four levels of development in the two dimensions: baseline, mixed, focused and extended noticing, as described in Table 41.1.

The practice of noticing is more likely to develop in contexts of collaborative sense-making of learner reasoning where teachers plan, observe and reflect on lessons together (Takahashi et al. 2013), such as lesson study.

\subsubsection{Lesson Study as a Context for the Development of Noticing}

Reflection and noticing are essential components of Japanese lesson study, a form of professional development aimed at the improvement of instruction (Lewis and Tsuchida 1998; Takahashi et al. 2013). Lesson study is the systematic and collaborative planning and reviewing of a research lesson by a community of teachers and a 'knowledgeable other' to bring together theoretical and practical learning in an authentic way. The lesson study cycle entails the collaborative planning of a lesson, the observation of the research lesson, and an in-depth post-lesson discussion (Lewis 2002; Pothen and Murata 2006). In some cases, the lesson is then revised and taught again, with another post-lesson reflection. The focus of a research lesson is on sense-making, building of mathematics concepts and problem solving. A lesson study group goes through multiple cycles of such inquiry over time, which leads to an improvement of their mathematical knowledge for teaching (Takahashi et al. 2013). This process fosters high-quality learning through high-quality teaching (Nishimura 2016). The improvement of teachers' professional knowledge and skills enables them to become expert teachers (high-quality teaching) who can progressively provide learners with opportunities for deep learning of content and in the process become independent learners and problem solvers (high-quality learning) (Sugiyama 2008; Takahashi et al. 2013). Groves et al. (2016) suggest that lesson study be adapted for other cultures and situations rather than adopting the Japanese model as is.

Noticing plays an important role in a lesson study cycle from the planning of the research lesson to observing and reflecting on the lesson. Mason's (2002) description of noticing as a set of practices that includes reflecting systematically, recognising choices and alternatives, preparing and noticing possibilities, and validating with others (p. 87) bears similarity to lesson study as deliberate practice (Miller 2011), as well as to the Gibbs' (1988) reflection cycle often used as a guide for pre-service teachers' reflection. 
Professional noticing resonates strongly with the goals of lesson study-planning for student learning, noticing how the tasks and activities foster or hamper learning during the lesson, interpreting what happened during the lesson and deciding how to plan and teach the lesson more efficiently in the future.

\subsection{Method}

In a longitudinal project, a cohort of pre-service teachers' reflections in a problem-centred mathematics teaching and learning context over a period of two years were investigated. The purpose of the project was to explore pre-service teachers' reflections on their own and observed research lessons in order to improve the structure and development of reflective mathematical practice in an undergraduate teacher education program. The research questions driving the larger investigation dealt with aspects of the problem-centred approach that pre-service teachers reflect on and their noticing during mathematics lessons. This paper only focuses on the latter: the development of prospective teachers' noticing over a two-year period.

\subsubsection{Context and Participants}

At Stellenbosch University, mathematics teacher education for prospective foundation phase teachers specialising to teach in Grades R to 3 (6- to 9-year-olds) is nested in a problem-centred approach to the teaching of mathematics as described in the work of Murray et al. (1998), Hiebert et al. (1997) and Stein et al. (2008). To facilitate and support pre-service teachers' in adopting a problem-centred approach and develop the relevant knowledge, skills and dispositions, an adapted form of Japanese lesson study is implemented as one of the contexts for their professional development. Structured reflection opportunities during lesson study cycles help bridge the theory-practice gap in this mostly unfamiliar context for the prospective teachers.

Pre-service teachers conduct school observations for two weeks in the beginning of the second and third years and nine weeks of school practicum in their second, third and fourth years. These practicum experiences are supplemented by two cycles of micro lessons $\left(\right.$ Fishbowl $^{1}$ ) in the first semester of the third year and a service-learning project in the first semester of the fourth year.

\footnotetext{
${ }^{1}$ The Fishbowl micro lessons comprise the teaching of a lesson by a pre-service teacher to a small group of learners while the lecturer and other pre-service teachers are observing behind one-way glass.
} 
Lesson study is used in the mathematics education module for foundation phase (Grades R to 3) during Fishbowl in the third year and school practice in the fourth year. In the third year, students participate in groups of six or seven of their own choice and complete two lesson study cycles. The Fishbowl lesson study cycles are the first exposure of pre-service teachers to lesson study. In the fourth year, three to seven pre-service teachers are grouped together based on the locations of their school practice schools for one lesson study cycle. The lecturer acts as 'knowledgeable other' during the lesson study processes. Pre-service teachers in groups study the curriculum and mathematics content area of their chosen topic and formulate an over-arching goal as well as specific goals for their research lesson. Lesson planning includes considering a possible learning trajectory for the topic and where the lesson would fit into this trajectory, developing a real-world task for the lesson, anticipating possible learner strategies and misconceptions, considering connections between the possible strategies, planning questions to elicit learner reasoning and planning how to summarise the lesson at the end. The research lesson is then presented by each of the group members in their own classes and observed by some of the other group members. The lesson subsequently is refined and finally presented by one of the group members while the lecturer as 'knowledgeable other' and all other group members observe. A post-lesson discussion with thorough reflection-on-action by all observers follows. The mentor teachers at the schools where the pre-service teachers are doing school practice are not involved in the lesson study process. After a lesson study cycle, pre-service teachers are required to submit individual written reflections on the research lessons as a consolidation of learning (Lewis et al. 2009). These reflections have to be submitted a week after the research lesson and are guided by questions based on the Gibbs reflection cycle (Gibbs 1988). This reflection framework, used by all lecturers in the Department of Curriculum Studies, focuses on what transpired during the lesson, an analysis of what went well or wrong and why in order to make sense of the situation and the exploration of alternatives and culminates in an action plan.

Participants were undergraduate prospective teachers preparing to teach mathematics at the foundation phase level (6- to 9-year-olds in Grades R to 3). They were all female, as most of the population of foundation phase teachers in the region are. Participants' experience of noticing before the Fishbowl lesson study cycles in the third year was limited to doing video analyses of a number of lessons in class. Although the terminology and framework of noticing were not used, the lesson analysis was focused on noticing learner reasoning and strategies and using inferences from what they noticed in order to plan subsequent lessons. In the fourth year, a unit of lectures on noticing precedes the school practicum. In the research and lesson planning phases in the lesson study cycles in the third and fourth years, specific attention is given to anticipated learner strategies and planning for noticing of children's mathematical reasoning, and examples are discussed. Due to logistical arrangements, lesson study groups for the two lesson study cycles in the third year are the same, but change for the cycle in the fourth year. For the same reason, post-lesson discussions are shorter in the case of the two Fishbowl research lessons than they are for the research lesson in the fourth year. The post-lesson reflection 
colloquia of the different lesson study groups in the fourth year are videoed to capture student teachers' reflections, but they are not in the third year. All ethical requirements of Stellenbosch University were adhered to in the research study.

Fifty-six out of the cohort of 59 fourth-year pre-service teachers volunteered their third and fourth year reflections for analysis in the study. Participants were from different language groups (Afrikaans, English and Xhosa), and research lessons were taught in either Afrikaans or English. Post-lesson colloquia were conducted in Afrikaans, English or both, depending on the mother tongues of the participants; pre-service teachers often switched between languages, as groups consisted of students from different language groups. Written reflections were in the language of their choice.

Students' reflections did not yield many rich descriptions of learner reasoning. After scrutinising all reflections, eight students whose reflections included descriptions of learner reasoning in at least one of the three data sets were selected and their reflections further analysed using the Van Es (2011) framework. Due to space constraints, three prospective teachers' noticing as evidenced in their reflections on three research lessons have been selected to be developed as case studies for this paper. These three pre-service teachers were not members of the same group in any of the three lesson study cycles.

\subsubsection{Data Generation}

Data were generated at the end of three lesson study cycles, two in the third year and one in the fourth year, and comprised videoed post-lesson discussions and written reflections after each of these lesson study cycles. During Fishbowl lesson study cycles, only written reflections were generated, whereas written and verbal reflections were collected during the school practicum lesson study cycles. The reflections of pre-service teachers were on research lessons they either observed or taught themselves and were on entire lessons, as in the research of Santagata (2011), and not only on video clips of lessons. During post-lesson reflections, students' individual accounts of what they noticed during lessons were recorded for analysis. Further elaboration from the group on individuals' noticing was not included in the analysis covered in this paper.

\subsubsection{Analysis}

Video and document analysis of verbal and written reflections were conducted using the Van Es (2011) framework for learning to notice student reasoning to determine what and how pre-service teachers noticed during research lessons and to determine how their noticing developed over the two-year period. Pre-service 
teachers' written and videoed reflections were coded according to the four levels of the Van Es (2011) framework and an independent researcher checked the researcher's interpretations of the data.

\subsection{Results}

To determine growth and depth in noticing over a period of two years, pre-service teachers' written reflections on two research lessons for Fishbowl in the third year and one verbal or written reflection on a research lesson in the fourth year were analysed. Reflections were in some cases on lessons the pre-service teachers themselves taught and in some cases on observed lessons.

\subsubsection{Case Studies}

In the three case studies below, unless stated that the student teacher taught the lesson being discussed, all reflections were on observed research lessons.

Case Study 1: Myra (participants' real names are not used)

Myra's written reflections on observed Fishbowl research lessons in the third year were analysed, as were her reflections on her own lesson during the fourth-year lesson study.

Fishbowl research lesson 1: Myra's written reflection on the Grade 2 lesson about money focused on the whole class and the teacher (whom), her noticing comprised teacher pedagogy and learner behaviour (what) and she gave general impressions and evaluative comments (how). Examples: 'Learners were interested in the theme of the lesson' and 'The teacher did not tell the learners how to solve the problem, she gave them space to decide on their own strategies'. Myra's noticing for this research lesson has been categorized as Level 1 (baseline; Table 41.2).

Fishbowl research lesson 2: In her written reflection, Myra's noticing during this Grade 2 lesson on capacity measurement again was general and evaluative, focusing on learner behaviour and teacher pedagogy. Examples: 'The activities were focused and well explained' and 'The learners were so carried away with the water and activity that they did not focus on the math'. Her noticing still was on Level 1 (baseline; Table 41.2).

School practicum research lesson: Myra taught this Grade 2 lesson on capacity measurement, and her reflections (during the videoed post-lesson discussion and written reflection) showed noticing about the learners as group but also shifted towards particular learners' mathematical behaviour and reasoning with comments such as "When they were estimating, I asked "What do you think?" One learner 
Table 41.2 Noticing levels of pre-service teachers in the sample

\begin{tabular}{l|l|l|l|l}
\hline & Baseline & Mixed & Focused & Extended \\
\hline $\begin{array}{l}\text { Research lesson 1 } \\
\text { Fishbowl (3rd year) }\end{array}$ & Myra $^{3}$ Ruda $^{3}$ & Charlie $^{3}$ & & \\
\hline $\begin{array}{l}\text { Research lesson 2 } \\
\text { Fishbowl (3rd year) }\end{array}$ & $\mathrm{Myra}^{3}$ & Charlie & Ruda $^{1,3}$ & \\
\hline $\begin{array}{l}\text { Research lesson 3 School } \\
\text { practicum (4th year) }\end{array}$ & & Charlie & Myra $^{1,2,3}$ Ruda $^{1,2,3}$ & \\
\hline
\end{tabular}

${ }^{1}$ Taught research lesson

${ }^{2}$ Verbal reflection

${ }^{3}$ Written reflection

guessed 84, the next one said another number and the third thought deeply and then said "I will then say 82" and "Christian said that the group tried to get their measurement close to their estimation'. She evidently was starting to notice particular learners' mathematical behaviour and reasoning, albeit primarily evaluating comments. Myra's noticing therefore shows progress from Level 1 in the second year to Level 3 (focused) in the fourth year (Table 41.2).

\section{Case Study 2: Ruda}

Fishbowl research lesson 1: Ruda's noticing in her written reflection for this 3-D geometry research lesson for Grade 2 was on Level 1 (baseline; Table 41.2). Her comments were of a general and evaluative nature and concerned learner behaviour, teacher pedagogy and classroom control as the following three examples show: 'The lesson showed me how important classroom control is', 'The teacher used normal household objects; they were easy to relate to and when learners go home, they will be able to apply the knowledge they had learnt' and 'Learners were excited; the teacher did not tell them how to sort the objects, they were able to use their own ideas'.

Fishbowl research lesson 2: The Grade 2 fraction research lesson that Ruda taught elicited the following comments from her in a videoed post-lesson discussion: 'There were slight differences in how learners shared the last chocolate bar. Some continued to share 1-1 until they were finished, some just drew 2 lines to the same chocolate and others shared it in pieces with a line' and 'Even though they didn't know the terminology, they knew it wasn't a whole chocolate that each person received'. She noticed and interpreted the mathematical behaviour and reasoning of both the learners as a group and specific learners but did not suggest any teacher moves based on these responses; therefore, her reflections can be categorised as Level 3 (focused; Table 41.2).

School practicum research lesson: Ruda's noticing in this Grade 2 lesson on multiplication that she taught again was on Level 3 (focused; Table 41.2). In a videoed post-lesson discussion, she referred to and elaborated on individual learners' mathematical reasoning, interpreting their reasoning. Examples: 'When you ask them to explain, they don't explain what they did. Like Max, he counted 1, $2,3,4,5,6,7,8$. He's not counting in 4 s, he's counting in ones. But when you ask 
him, he says "I'm counting in 4s". I am sure if I asked him, he would be able to count 4, 8, 12...' and 'And like Melissa, she drew groups first, then she made lines in them, and then I asked "What did you do" and she said "I am counting in $4 \mathrm{~s}$ ". They don't always explain how they did it; they know they are supposed to be counting in $4 \mathrm{~s}$, so they say "I counted in $4 \mathrm{~s}$ ",

Ruda's noticing therefore progressed over the period of two years, from the Level 1 in the lesson study cycle one to the Level 3 in cycles two and three.

\section{Case Study 3: Charlie}

Fishbowl research lesson 1: This written reflection was on a Grade 2 lesson on mass measurement. Charlie highlighted a noteworthy event during the lesson and drew inferences from learner mathematical reasoning, but generalized her comments to the group of learners rather than commenting on individual learners' reasoning: 'Six out of 10 learners approached the problem incorrectly or miscalculated. It could be that they are not used to coming up with their own strategies or that the problem was too difficult for them to make sense of it'. Charlie tended to generalise individuals' reasoning to collective reasoning of the group. Her noticing for this lesson study cycle was categorised as Level 2 (mixed), bordering on Level 3 (focused; Table 41.2).

Fishbowl research lesson 2: This Grade 2 lesson also was on mass measurement. Charlie noticed and provided evaluative comments about an individual learner's mathematical behaviour and reasoning in her written reflection on the lesson: 'One boy's measurement units (he used nuts) were not quite enough to measure- he was quite confused when his first strategy didn't work. It was fantastic to see how he came up with another plan to solve the problem'. Her comments were descriptive and not interpretive; therefore, her comment is categorised as Level 2 (mixed; Table 41.2).

School practicum research lesson: This Grade 2 lesson on length measurement prompted comments about teacher pedagogy and the mathematical understanding of groups of learners as well as of individuals in a videoed post-lesson discussion: 'The focus shifted and a valuable discussion was lost. Learners did not have a discussion about how the different ways of measuring can influence their measurements and what they should be doing to get similar answers' and 'The teacher over-emphasised the way they should hold their hands when they are measuring. This became a requirement instead of the class understanding the concepts of measurement and the necessity to measure accurately'. Reference to and interpretation of specific events and actions show Level 2 noticing (mixed) bordering on Level 3 noticing (focused; Table 41.2).

\subsubsection{Case Studies Summary}

From Table 41.2 it is evident that verbal reflections during post-lesson discussions were on Level 2 or 3, while written reflections were spread over the first three 
levels. Furthermore, student teachers' reflections (Ruda: Lessons 2 and 3; Myra: Lesson 3) on their own lessons were all on the level of focused noticing (Level 3). Five of the six reflections in the third year (the first two lesson study cycles) were on the first two levels, with a shift to a higher level of noticing during the school practicum (third lesson study cycle) in the fourth year for two of the three pre-service teachers.

\subsection{Discussion}

In this study, which has been framed by research on reflection, noticing and lesson study, the Van Es (2011) framework for learning to notice has been used to track the development of pre-service teachers' noticing over the last two years of their studies. The backdrop of a problem-centred approach to the teaching of mathematics and a focus on the development of mathematical reasoning was especially important in the prospective teachers' four-year course as well as in the lesson study cycles during which the data were generated.

The findings indicate that two of the pre-service teachers made a positive shift towards higher levels of noticing from the third to the fourth year, although not to the highest level of extended noticing. This finding corroborates Korthagen et al. (2006) statement that pre-service teachers do not always adopt what they learn during their preparation programs. The third student teacher stayed on the same level for all three lesson study cycles. This is in line with Jacobs et al. (2010) and Santagata (2011) research, which indicated that a considerable number of pre-service teachers have trouble with noticing and attending to specific learner strategies. Post-lesson discussions elicited more productive noticing than written reflections, with more explicit references to individual learners' reasoning and more attempts at interpreting what they noticed. In written reflections, pre-service teachers tended to generalise individual learners' reasoning or comment on individuals' reasoning as being the collective reasoning of a group or the class. However, in written reflections, pre-service teachers made stronger connections between learner reasoning and behaviour and principles of teaching and learning, suggesting possible alternative teacher questions and moves. This might be a result of the nature of the four Gibbs (1988) reflection questions, which encourage more of a summary of what has been noticed, resulting in more general than specific comments.

Reflections on lessons that pre-service teachers themselves taught also showed more productive noticing than reflections on observed lessons. This could be due to the fact that the pre-service teacher teaching the lesson was more familiar with the learners in the classroom (Sherin et al. 2011b). Furthermore, although the lessons have been planned jointly, pre-service teachers may have taken more ownership of the lessons they taught (Takahashi et al. 2013) and may therefore have been more attuned to learners' reasoning during the lesson than the rest of the observing group. 
During post-lesson discussions, the lecturer as 'knowledgeable other' first facilitated pre-service teachers reflections, where she focused their attention on the reasoning of individual learners, pointing out other alternatives and asking them to make sense of learner reasoning and its implications for teaching, therefore introducing her own higher level noticing and modelling the practice of noticing. This modus operandi is consistent with the practice of lesson study where the role of the 'knowledgeable other' includes bringing new knowledge about research and the curriculum, pointing out connections between theory and practice and helping teachers' 'to learn how to reflect on teaching and learning' (Takahashi 2013, p. 12). In the research of Van Es (2011), the facilitators of the video club also offered alternative perspectives and modelled to participants in the video club how to engage in the practice of noticing and reasoning about learner reasoning. This 'helped the group recognize multiple valid interpretations of a student idea and the value of further inquiry as ways to clarify the issue under discussion' (p. 148) and resulted in 'more substantive analyses of student thinking' (p. 148).

Kassim (2016), in a study of a cohort of pre-service foundation phase teachers at the end of their third year who were all following the same course at the same university, found that pre-service teachers perceived an improvement in their mathematical knowledge for teaching during their third year, enabling them to create effective mathematical instruction using learners' understanding and reasoning and to address their misconceptions. Participants in Kassim's study also perceived a marked change in their beliefs towards implementing a problem-centred approach 'where learners express their own understanding of the problem, engage learners' interactive discussions to enhance their reasoning and understanding' and 'assist learners to solve problems using their own strategies' (p. 377). It can therefore be speculated that a change in pre-service teachers' beliefs and mathematical knowledge during the third year might have contributed to their higher level of noticing in the fourth year.

The fact that participants were from different language groups and switched between languages during discussions could have had an influence on their expression of what and how they noticed. Although all prospective teachers are bilingual, they sometimes struggle to express themselves clearly in their second language (Setati et al. 2002; Webb and Webb 2008).

Research by Choy (2015), Posthuma (2012) and Takahashi et al. (2013) points to lesson study as a productive environment for reflection and the development of noticing in a teacher preparation program. These authors highlight aspects of lesson study that contribute to making it a productive context for fostering reflection and noticing. These aspects include focus on the development of mathematical thinking (Takahashi and McDougal 2016), a very thorough process of planning for student learning (Choy 2016), noticing of how tasks and activities foster learning during a lesson, interpretation of learner thinking during the lesson, and decision making about ways to plan and teach the lesson more efficiently in future (Lewis et al. 2009).

Pre-service teachers' noticing in the current study did not all progress as hoped, and more research is needed to determine the reasons behind these findings. Gaps in 
the pre-service teachers' preparation and the influence of different aspects in the process of lesson study such as group size, format of the reflections, limited time reflection after Fishbowl and the knowledge and beliefs of the pre-service teachers' could all have an influence and will have to be investigated.

\subsection{Limitations and Future Research}

The findings in this small-scale study cannot be generalised. Larger-scale longitudinal studies are needed to track the development of prospective teachers' noticing during their preparation programs and even into their first years of practice (Barnhart and Van Es 2015). The lesson study process fostered the development of more productive noticing, but pre-service teachers' noticing may also have been influenced by lecturers in other subjects encouraging them to reflect or the use of specific protocols to structure reflection. The noticing framework does not make provision for noticing of task characteristics or how learners responded to the task and can be extended to include such aspects of lessons.

More research is needed on the difference between prospective teachers' verbal and written reflections and the influence of their mathematical knowledge for teaching on their noticing and development of reflection skills. The role of lesson topics in noticing is also not clear.

\subsection{Conclusion}

Pre-service teachers need purposeful, structured opportunities and appropriate experiences to reflect on and make sense of learner mathematical reasoning: 'This expertise can be learned and ... both teaching experience and professional development support this endeavor' (Jacobs et al. 2010, p. 191). Lesson study as situated in a problem-centred context where learners' mathematical reasoning takes centre stage has proven a productive context for such professional development and experiences. Noticing frameworks are useful for not only assessing growth and depth in noticing but should also be used as guides for scaffolding pre-service teachers' noticing skills when observing live as well as videoed lessons. Teaching for understanding is one of the hallmarks of a problem-centred approach to the teaching of mathematics, and noticing in teacher preparation programs needs to be framed in the bigger picture of learning to teach mathematics for understanding. 


\section{References}

Anderson, L., \& Krathwohl, D. (2001). A taxonomy for learning, teaching, and assessing: A revision of bloom's taxonomy of educational objectives. New York: Longman.

Ball, D., Lubienski, S., \& Mewborn, D. (2001). Research on teaching mathematics: The unsolved problem of teachers' mathematical knowledge. In V. Richardson (Ed.), Handbook of research on teaching (4th ed., pp. 433-456). New York: Macmillan.

Ball, D., Thames, M., \& Phelps, G. (2008). Content knowledge for teaching: What makes it special? Journal of Teacher Education, 59(5), 389-407.

Barnhart, T., \& Van Es, E. (2015). Studying teacher noticing: Examining the relationship among pre-service science teachers' ability to attend, analyze and respond to student thinking. Teaching and Teacher Education, 45, 83-93.

Choy, B. (2014). Teachers' productive mathematical noticing during lesson preparation. In 38th Conference of the International Group for the Psychology of Mathematics Education (PME38) and the 36th Conference of the North American Chapter for the Psychology of Mathematics Education (PME-NA36) (pp. 297-304). Vancouver, Canada.

Choy, B. (2015). The FOCUS framework: Snapshots of mathematics teacher noticing (Doctoral thesis in Philosophy in Mathematics Education). University of Auckland.

Choy, B. (2016). Snapshots of mathematics teacher noticing during task design. Mathematics Education Research Journal, 28, 421-440. https://doi.org/10.1007/s13394-016-0173-3.

Dewey, J. (1933). How we think: A re-statement of the relation of reflective thinking in the educative process. Chicago: Henry Regnery.

Erickson, F. (2011). On noticing teacher noticing. In M. Sherin, V. Jacobs, \& R. Philipp (Eds.), Mathematics teacher noticing: Seeing through teachers' eyes (pp. 17-34). New York, NY: Routledge.

Fennema, E., Carpenter, T., Francke, M., Levi, L., Jacobs, V., \& Empson, S. (1996). Mathematics instruction and teachers' beliefs: A longitudinal study of using children's thinking. Journal for Research in Mathematics Education, 27, 403-434.

Fernández, C., Llinares, S., \& Valls, J. (2012). Learning to notice students' mathematical thinking through online discussions. ZDM Mathematics Education, 44, 747-759.

Fernández, C., Llinares, S., \& Valls, J. (2013). Primary teacher's professional noticing of students' mathematical thinking. The Mathematics Enthusiast, 10(1\&2), 441-468.

Galbraith, P. (2015). 'Noticing' in the practice of modelling as real world problem solving. In G. Kaiser, \& H.-W. Henn (Eds.), Werner Blum und seine Beiträge zum Modellieren im Mathematikunterricht: Festschrift zum 70. Geburtstag von Werner Blum (pp. 151-166). Wiesbaden: Springer. https://doi.org/10.1007/978-3-658-09532-1_11.

Gibbs, G. (1988). Learning by doing: A guide to teaching and learning methods. Oxford: Further Education Unit, Oxford Brookes University.

Goldsmith, L., Doerr, H., \& Lewis, C. (2014). Mathematics teachers' learning: A conceptual framework and synthesis of research. Journal of Mathematics Teacher Education, 17(1), 5-36.

Grossman, P., Hammerness, K., \& McDonald, M. (2009). Redefining teaching, re-imagining teacher education. Teachers and Teaching, 15(2), 273-289. https://doi.org/10.1080/ 13540600902875340.

Groves, S., Doig, B., Vale, C., \& Widjaja, W. (2016). Critical factors in the adaptation and implementation of Japanese Lesson Study in the Australian context. ZDM Mathematics Education, 48, 501-512. https://doi.org/10.1007/s11858-016-0786-8.

Hiebert, J., Carpenter, T., Fennema, E., Fuson, K., Wearne, D., Murray, H., et al. (1997). Making sense: Teaching and learning mathematics with understanding. Portsmouth: Heinemann. 
Hiebert, J., Morris, A., \& Glass, B. (2003). Learning to learn to teach: An 'experiment' model for teaching and teacher preparation in mathematics. Journal of Mathematics Teacher Education, 6, 201-222.

Hill, H., Blunk, M., Charalambous, C., Lewis, J., Phelps, G., Sleep, L., et al. (2008). Mathematical knowledge for teaching and the mathematical quality of instruction: An exploratory study. Cognition and Instruction, 26, 430-511.

Jacobs, V. R., Lamb, L. C., \& Philipp, R. (2010). Professional noticing of children's mathematical thinking. Journal for Research in Mathematics Education, 41(2), 169-202.

Kassim, A. (2016). Perceptions of pre-service teachers in Foundation Phase mathematics about their professional development (Unpublished doctoral dissertation). Stellenbosch University.

Kazemi, E., Elliot, R., Mumme, J., Carroll, C., Lesseig, K., \& Kelly Peterson, M. (2011). Noticing leaders' thinking about videocases of teachers engaged in mathematics tasks in professional development. In M. Sherin, V. Jacobs, \& R. Philipp (Eds.), Mathematics teacher noticing: Seeing through teachers' eyes (pp. 188-203). New York, NY: Routledge.

Korthagen, F. (2007). The gap between research and practice revisited. Educational Research and Evaluation, 13(3), 303-310. https://doi.org/10.1080/13803610701640235.

Korthagen, F., Loughran, J., \& Russell, T. (2006). Developing fundamental principles for teacher education programs and practices. Teacher and Teacher Education, 22(8), 1020-1041.

Lampert, M. (2001). Teaching problems and the problems of teaching. New Haven, CT: Yale University Press.

Lewis, C. (2002). A handbook of teacher-led instructional change. Philadelphia: Research for Better Schools.

Lewis, C., Perry, R., \& Hurd, J. (2009). Improving mathematics instruction through lesson study: A theoretical model and North American case. Journal of Mathemaitcs Teacher Education, 12, 285-304. https://doi.org/10.1007/s10857-009-9102-7.

Lewis, C., \& Takahashi, A. (2013). Facilitating curriculum reforms through lesson study. International Journal for Lesson and Learning Studies, 2(3), 207-217. https://doi.org/10.1108/ IJLLS-01-2013-0006.

Lewis, C., \& Tsuchida, I. (1998). A lesson is like a swiftly flowing river: Research lessons and the improvement of Japanese education. American Educator, 14-17, 50-52.

Llinares, S. (2013). Professional noticing: A component of the mathematics teacher's professional practice. SISYPHUS Journal of Education, 1(3), 76-93.

Mason, J. (2002). Researching your own practice: The discipline of noticing. London: Routledge Falmer.

Mason, J. (2011). Noticing: Roots and branches. In M. Sherin, V. Jacobs, \& R. Philipp (Eds.), Mathematics teacher noticing: Seeing through teachers' eyes (pp. 35-50). New York, NY: Routledge.

Miller, K. (2011). Situation awareness in teaching. In M. Sherin, V. Jacobs, \& R. Philipp (Eds.), Mathematics teacher noticing: Seeing through teachers' eyes (pp. 51-65). New York, NY: Routledge.

Mitchell, R., \& Marin, K. (2015). Examining the use of a structured analysis framework to support prospective teacher noticing. Journal of Mathematics Teacher Education, 18, 551-575. https:// doi.org/10.1007/s10857-014-9294-3.

Murray, H., Olivier, A., \& Human, P. (1998). Learning through problem solving. In Olivier, A, \& Newstead, K (Ed.), Proceedings of the Twenty-second International Conference for the Psychology of Mathematics Education (Vol. 1, No. 1, pp. 169-185). Stellenbosch.

Nishimura, K. (2016). Lesson study at the upper secondary level in Japan. In Presentation, Lesson Study Mini Conference. Nottingham, UK. 
Paolucci, C., \& Wessels, H. (2017). An examination of pre-service teachers' capacity to create mathematical modeling problems for children. Journal of Teacher Education, 68(3), 330-344. https://doi.org/10.1177/002248711769763.

Posthuma, A. (2012). Mathematics teachers' reflective practice within the context of adapted lesson study. Pythagoras, 33(3). https://doi.org/10.4102/pythagoras.v33i3.140.

Pothen, B., \& Murata, A. (2006). Developing reflective practitioners: A case study of pre-service elementary mathematics teachers' lesson study. In J. V. S. Alatore (Ed.), Proceedings of the 28th Annual Meeting of the North American Chapter of the International Group for the Psychology of Mathematics Education (Vol. 2, pp. 824-826). Merida, Mexico: Universidad Pedagogica Nacional.

Santagata, R. (2011). From teacher noticing to a framework for analyzing and improving classroom lessons. In M. Sherin, V. Jacobs, \& R. Philipp (Eds.), Mathematics teacher noticing: Seeing through teachers' eyes (pp. 152-168). New York, NY: Routledge.

Santagata, R., Zannoni, C., \& Stigler, J. (2007). The role of lesson analysis in pre-service teacher education: An empirical investigation of teacher learning from a virtual video-based field experience. Journal of Mathematics Teacher Education, 10(2), 123-140.

Schoenfeld, A. (2011). Noticing matters. A lot. Now what? In M. Sherin, V. Jacobs, \& R. Philipp (Eds.), Mathematics teacher noticing: Seeing through teachers' eyes (pp. 223-238). New York: Routledge.

Schön, D. (1987). Educating the reflective practitioner. San Francisco: Jossey-Bass.

Seidel, T., \& Stürmer, K. (2014). Modeling and measuring the structure of professional vision in pre-service teachers. American Educational Research Journal, 51(4). https://doi.org/10.3102/ 0002831214531321.

Setati, M., Adler, J., Reed, Y., \& Bapoo, A. (2002). Incomplete journeys: Code-switching and other language practices in mathematics, science and english language classrooms in South Africa. Language and Education, 16(2), 128-149.

Sherin, M. G, Jacobs, V. R, \& Philipp, R. A. (2011a). Situating the study of teacher noticing. In M. Sherin, V. Jacobs, \& R. Philipp (Eds.), Mathematics teacher noticing: Seeing through teachers' eyes (pp. 3-13). New York, NY: Routledge.

Sherin, M. G., Jacobs, V. R., \& Philipp, R. A. (2011b). Mathematics teacher noticing: Seeing through teachers' eyes. New York, NY: Routledge.

Sherin, M., Russ, R., \& Colestock, A. (2011c). Accessing mathematics teachers' in-the-moment noticing Chapter 6. In M. Sherin, V. Jacobs, \& R. Philipp (Eds.), Mathematics teacher noticing: Seeing through teachers' eyes (pp. 79-94). New York, NY: Routledge.

Stein, E., Engle, R., Smith, M., \& Hughes, E. (2008). Orchestrating productive mathematical discussions: Five practices for helping teachers move beyond show and tell. Mathematical Thinking and Learning, 10, 313-340.

Stigler, J., \& Hiebert, J. (1999). The teaching gap. Best ideas from the world's teachers for improving education in the classroom. New York: Free Press.

Sugiyama, Y. (2008). Introduction to elementary mathematics education. Tokyo: Toyokan Publishing Co. (In Japanese.)

Takahashi, A. (2013). The role of the knowledgeable other in lesson study: Examining the final comments of experienced lesson study practitioners. Mathematics Education Research Group of Australasia.

Takahashi, A., Lewis, C., \& Perry, R. (2013). A US lesson study network to spread teaching through problem solving. International Journal for Lesson and Learning Studies, 2(3), 237255. 
Takahashi, A., \& McDougal, T. (2016). Collaborative lesson research: Maximizing the impact of lesson study. ZDM Mathematics Education, 513-526. https://doi.org/10.1007/s11858-0150752-x.

Van Es, E. (2011). A framework for learning to notice student thinking. In M. Sherin, V. Jacobs, \& R. Philipp (Eds.), Mathematics teacher noticing: Seeing through teachers' eyes (pp. 134-151). New York: Routledge.

Webb, L., \& Webb, P. (2008). Introducing discussion into multilingual mathematics classrooms: An issue of code switching. Pythagoras, 67, 26-32.

Open Access This chapter is licensed under the terms of the Creative Commons Attribution 4.0 International License (http://creativecommons.org/licenses/by/4.0/), which permits use, sharing, adaptation, distribution and reproduction in any medium or format, as long as you give appropriate credit to the original author(s) and the source, provide a link to the Creative Commons license and indicate if changes were made.

The images or other third party material in this chapter are included in the chapter's Creative Commons license, unless indicated otherwise in a credit line to the material. If material is not included in the chapter's Creative Commons license and your intended use is not permitted by statutory regulation or exceeds the permitted use, you will need to obtain permission directly from the copyright holder. 